University of Wollongong

Research Online

Faculty of Law, Humanities and the Arts Papers (Archive)

Faculty of Arts, Social Sciences \& Humanities

$1-1-2017$

The drivers of firm longevity: age, size, profitability and survivorship of Australian corporations, 1901-1930

Laura Panza

University of Melbourne

Simon Ville

University of Wollongong, sville@uow.edu.au

David Merrett

University of Melbourne

Follow this and additional works at: https://ro.uow.edu.au/lhapapers

Part of the Arts and Humanities Commons, and the Law Commons

Research Online is the open access institutional repository for the University of Wollongong. For further information contact the UOW Library: research-pubs@uow.edu.au 


\title{
The drivers of firm longevity: age, size, profitability and survivorship of Australian corporations, 1901-1930
}

\author{
Abstract \\ Why do some firms last longer than others? This question has attracted considerable interest among \\ scholars from business history, management and economics. Our article combines the business \\ historian's macro view of the relationship between size, longevity, and economic development with \\ quantitative modelling. We apply survival analysis to data relating to size, age and profitability, three first- \\ order explanations of longevity, for Australian stock exchange (ASX) listed corporations from 1901 to \\ 1930. The novelty of the article is twofold: we find that firm size is a poor predictor of longevity for the full \\ sample but its age and profitability are highly significant; our data covers a longer time frame and relates \\ to a rich mid-sized and non-industrialised country.

\section{Disciplines} \\ Arts and Humanities | Law

\section{Publication Details} \\ Panza, L., Ville, S. \& Merrett, D. (2018). The drivers of firm longevity: age, size, profitability and survivorship \\ of Australian corporations, 1901-1930. Business History, 60 (2), 157-177.
}


The drivers of firm longevity: age, size, profitability and survivorship of Australian corporations, 1901-1930

Laura Panza, ${ }^{\mathrm{a}}$ Simon Ville, ${ }^{\mathrm{b}}$ and David Merrett ${ }^{\mathrm{c}}$

Acknowledgements

The authors gratefully acknowledge financial support from the Faculty of Business and Economics, University of Melbourne and from the Australian Research Council under the Discovery Projects scheme (project 0557412). We thank Andrew Parnell and Taehyun Ryu for excellent research assistance and the participants at the Asia Pacific Economic and Business History Conference 2016 for helpful comments. All remaining errors are our own.

\footnotetext{
${ }^{\text {a }}$ University of Melbourne, Melbourne, Australia.

${ }^{\mathrm{b}}$ University of Wollongong, Wollongong, Australia. *Corresponding author. Email: sville@uow.edu.au.

${ }^{\mathrm{c}}$ University of Melbourne, Melbourne, Australia.
} 
The drivers of firm longevity: age, size, profitability and survivorship of Australian corporations, 1901-1930

\begin{abstract}
Why do some firms last longer than others? This question has attracted considerable interest among scholars from business history, management and economics. Our paper combines the business historians' macro view of the relationship between size, longevity, and economic development with quantitative modelling. We apply survival analysis to data relating to size, age and profitability, three first-order explanations of longevity, for Australian stock exchange listed corporations from 1901 to 1930. The novelty of the paper is twofold: we find that firm size is a poor predictor of longevity for the full sample but its age and profitability are highly significant; our data covers a longer time frame and relates to a rich mid-sized and non-industrialised country.
\end{abstract}

Keywords: survivorship, firm size, profitability, big business, industry lifecycles, business history. 


\section{Introduction}

A recent Special Issue of this journal ${ }^{1}$ reminds us that understanding the drivers of a firm's lifespan matters. For those that survive longer than average, it is indicative of an organisation able to ride the cycles of change, be they economic, political or social. Any firm that continued in business throughout the first third of the twentieth century had to conjure with a world war, a severe economic slump, and competitive pressures from rivals. To do so suggests, beyond a measure of serendipity, an ability to build internal capabilities to help ride out these storms and exploit the opportunities. Survivorship also reveals something about the cohort of firms' contribution to a nation's corporate and economic development. Longevity, as well as size, shapes a firm's broader influences, for better or worse, on its sector and sometimes the national and international economy.

Surprisingly, there is no consensus about why some firms survive longer than others. Despite a wide literature that spans business history, management and economics, this is not a settled issue within or across disciplinary boundaries. There is little uniformity in type of empirical data used, the time span covered, or the explanatory models deployed. ${ }^{2}$ An underlying problem is that each of the disciplines has given priority to different metrics of performance, notably longevity, size, or profitability, as a proxy for sustainable competitive advantage. Moreover, each of these measures is the net result of interacting and potentially contradictory factors such as internal resources and dynamic capabilities, and external factors such as shifting competitive advantages and technological disruption.

We contribute to a better understanding of what determines firm survival through a study of a large sample of Australian listed companies in the first three decades of the twentieth century, a sample that ranges across firms from most sectors and different sizes. Our approach applies survival analysis to firm-level data in order to examine the relative importance of size, age and profitability to the longevity of Australian corporations from 1901 to 1930 . Our country-specific data and time period of 30 years enables us to tease out more holistic influences on our results than are to be found in the many studies undertaken by economists. The results shift the focus of business historians away from the largest firms to those that last longest, to reveal that smaller firms within our sample continued to thrive and survive. Moreover, we find that size has zero predictive power on longevity for the full sample: age and profitability are what mattered most. The strength of these results is confirmed by a series of robustness exercises, testing whether firms with specific characteristics (based on their location, size, type of production and foreign versus local 
ownership) behaved differently from the others or were the drivers of our findings. We show that manufacturing firms, which enjoyed tariff protection, represented an exception: for this sub-set of companies the drivers of longevity were age and size, but not profitability. The survivorship of small and medium enterprises in Australia raises questions about narratives and hypotheses that place large scale enterprise at the centre of a nation's business and economic development.

The paper will proceed in a number of steps. The next section will briefly review the questions raised about longevity by business historians, management scholars and economists, and the need for a more holistic approach to the question. The third section will situate our study in the context of the development of the Australian economy in the late nineteenth, and first part of the twentieth, century. We will present our data for each of the variables in section four. The methodology and the results are provided in section five. A discussion of the results and their implications for the literature will be presented in section six, followed by a brief conclusion.

\section{Integrating the study of business longevity}

The economist Alfred Marshall speculated about the inevitable demise of all firms using a biological metaphor, the trees of the forest. He was particularly interested in the new class of large scale enterprise emerging by the beginning of the twentieth century, which he believed stood out as the giant redwoods of the corporate forest by enduring much longer than the rest. ${ }^{3}$

The longevity of firms is a topic that has attracted the interest of scholars across a spectrum of disciplines, time periods, and geographic locations. ${ }^{4}$ Unsurprisingly, it has been approached from diverse perspectives using varied methodologies; even to the point of defining longevity in different ways and debating whether to focus on survival or failure. ${ }^{5}$ Some scholars have worked backwards, taking a group of exceptional firms and searching for drivers of their success amongst a range of firm-specific variables. ${ }^{6}$ The main interest, though, is to explain why some firms have endured longer than others.

At the highest level of abstraction, the interaction of a firm with its environment ultimately determines its fate. Each firm encounters both opportunities and challenges in a changing environment - such as industry characteristics, macroeconomic fluctuations, government policy shifts, and even armed conflicts - and must devise effective responses - 
or firm based capabilities - as best it can. Drawing upon several strands of theory, particularly from evolutionary economics and business strategy, authors have devised a series of explanatory models to reflect these exogenous and endogenous forces: environmental characteristics, organisational characteristics, and the entrepreneur's personal characteristics. ${ }^{7}$ The extensive contributions of Michael Porter have been particularly important in conceptually connecting these broad explanations to show how the effectiveness of a firm's set of resources depends on its ability to respond to the prevailing technology, markets and competitor actions. ${ }^{8}$ In turn, as David Teece has explained, dynamic capabilities describe how firms adapt to a changing environment by developing new organisational and strategic routines. $^{9}$

Valuable though these and other theoretical contributions are, it is difficult to measure many of these variables, particularly those that are endogenous to the firm and play out over longish periods of time. For all the sophistication of the resource-based view of the firm literature, in particular, it contains little empirical underpinning. ${ }^{10}$ This is hardly surprising given that the firm's competences and capabilities are unknowable to outsiders and that the tacitness of knowledge supporting organizational routines is not fully understood by the firms themselves. It can take many years, even decades, for most firms in a large cohort to have ceased trading. ${ }^{11}$ Therefore, understanding the underlying explanations of corporate survival or failure is especially well served by a longitudinal and empirical approach that history is well-equipped to provide. The early business history literature, led by Alfred Chandler, followed Marshall in believing that large scale enterprises developed the scale and capabilities to survive longer than other firms. ${ }^{12}$ Alternative explanations have since emerged with age and ownership especially implicated as we discuss later.

Riviezzo, Skippari and Garofano have provided a wide-ranging survey of research on business longevity in a special issue of Business History devoted to the topic, particularly focussing on the disciplinary contributions by business history and management scholars to this question. ${ }^{13}$ While they identify overlapping approaches and an increased rate of publications in the last decade, neither discipline deviates far from its intellectual origins: management (and economics) scholars focus on quantitative, theoretically-informed and relatively contemporary research, while business historians approach the question largely through qualitative, case study narratives. Nor is there much evidence of an exchange of ideas with cross-citation rates being very limited. 
The authors conclude by calling for a more integrated and interdisciplinary approach to longevity, particularly by utilising the expertise of both management and business history scholars. ${ }^{14}$ Napolitano, Marino and Ojala, in the same special issue of Business History, call for an approach to the study of business longevity that integrates the endogenous and exogenous explanations in order, 'to assess the time-varying effects of organisational variables - like size, age - and environmental characteristics - like density, competition level, and industry life cycle - on firms' chances of survival'. ${ }^{15}$

Our contribution responds to these calls. The organizational ecology literature models the rates of mortality amongst a population of firms or organizations over time with emphasis on environmental factors. ${ }^{16}$ Following that research methodology, we provide a duration model to explain the longevity of firms. In spite of this quantitative methodology, our work is an historical study - we examine Australia in the first three decades of the twentieth century, drawing deeply upon the literature and reasoning of business history. In the model we test three heavily theorised organisational explanations of longevity, notably firm size, age, and profitability. Our approach is bolstered by its economy wide coverage, which means the national environment is constant for all firms.

\section{Australian economic development}

The future of firms in our sample was shaped by the nature and course of Australian economic development. We focus on the first thirty years after Federation, which was a key period for Australian companies as it includes the formative years of the Australian corporate economy. In addition, it was a time of significant environmental change and disruption, through war and economic depression, which successful firms had to negotiate. Australia's place as one of the richest nations in the world around the beginning of the twentieth century came from its natural resources rather than from industrialisation. The country had flourished in the first global economy, enjoying a tight connection with a Great Britain that provided people, capital and templates for political institutions and legal systems that protected property rights. ${ }^{17}$ The macro-economic environment up to 1930 was subject to a number of shocks including a deep depression in the 1890s, the dislocation of trade and capital markets and the loss of manpower to the armed forces during World War I, a sharp post-war recession and the onset of the interwar depression. ${ }^{18}$ 
Despite this series of demand shocks, the supply-side capacity of the economy continued to grow apace up to 1930: the labour force expanded by two-thirds ${ }^{19}$ and its skill levels were augmented by immigration and rising participation rates in schooling and vocational training, ${ }^{20}$ a higher national savings rate was allocated to investors by financial intermediaries and equity markets ${ }^{21}$ technological standards were lifted by innovation, imitation and government funded scientific agencies assisting the rural industries; ${ }^{22}$ new sources of energy, electricity and oil, powered factories, offices, cars and $\operatorname{ships}^{23}$; and more land was used as pasture and brought under the plough. ${ }^{24}$

Simon Ville concluded that 'most enterprise in nineteenth-century Australia remained small-scale and owner-managed. However, some leviathans had begun to emerge that would cast a shadow over the corporate sector in the twentieth century; each increasingly developed its internal management systems as they grew but with limited evidence of generally agreed best practices'. ${ }^{25}$ One can argue that the firms in our sample that began their lives before the turn of the century, having already ridden the opportunities of economic expansion of the 1870 s and 1880s and the challenges of the 1890 s crisis, were better prepared to amass resources and build capabilities over the next 30 years. There are reasons for supposing that the internal resources and capabilities of those surviving firms strengthened over time. First, many more firms became incorporated and listed on local stock exchanges. ${ }^{26}$ This provided access to equity finance and over the long-haul divorced the life span of the business from the generational cycle of the founders by separating ownership from control exercised by a professional class. ${ }^{27} \mathrm{We}$ also believe that business practices improved over time through a growing standardisation of routines within industries, a codification of professional knowledge, and the dissemination of information by trade associations. ${ }^{28}$

Family firms, while of considerable importance in a number of European countries, have remained largely invisible in Australia and so have been excluded from our study. Only a small number of histories, of variable quality, have been produced, too small a number to permit any generalisations about them as a distinct business genre. A lack of publically available financial data for such businesses made it impossible to add them into our data set.

Chandler's explanation of the rise of the modern industrial enterprise in the United States of America rests heavily on the ability of firms in the science-based and capitalintensive manufacturing industries to capture economies of scale that allow them to under-cut their rivals' costs. ${ }^{29}$ Australia was different in that its economy was populated by large incorporated firms across mining, rural production, service and construction activity as well 
as manufacturing. Another point of difference was that Australia offered few opportunities for manufacturing industries of the second industrial revolution because of its small population, $6.6 \mathrm{~m}$ by $1933,{ }^{30}$ and poor internal transport links. There is evidence of scale economies emerging in parts of manufacturing, such as processing primary metals, and in some service industries notably banks, insurers and stock and station agencies, that led to exits and horizontal takeovers. However, the scale achieved in Australian markets left its largest firms as no more than minnows during these decades compared with firms in similar industries in the major industrial economies. ${ }^{31}$

\section{Data}

. Our dataset covers nearly 350 private sector firms listed on the state stock exchanges for which we have information regarding their date of incorporation, size and profitability. ${ }^{32}$ The main source is the Australian Insurance and Banking Review (AIBR), the leading business journal from the 1870s until the inter-war years. ${ }^{33}$ Despite its title, AIBR covered firms across all sectors and sought to include all listed companies. It provides no information, though, on sources of ownership. Of the 349 firms within the sample, 239 started life before, or in, 1901 and the remaining 110 were 'born' between 1902 and $1921 .{ }^{34}$ In the empirical analysis we utilise both datasets to test our hypotheses. We chose the period 1901-30 not only because of its macroeconomic characteristics, but also because, as shown below in Figure 1, it was long enough to affect the longevity of firms in our sample. For instance, around a third of them had exited by 1930, but it took the number of survivors another 70 years before falling away to a handful.

The population of firms is predominantly domestic with a small number of foreign firms, nearly all of whom were British. A few of the Australian companies had some business operations in foreign countries but these were a tiny part of their total revenues or assets. ${ }^{35}$ Government-owned enterprises operated as monopolists in transport, communications, and increasingly in gas and electricity production and distribution. Their longevity was a matter of political will rather than commercial success and they were not listed on the stock exchanges. ${ }^{36}$ Thus, they have not been considered in our analysis.

Unfortunately, we do not have access to data on firm-specific characteristics, such as the quality of management, decision-making or the nature and importance of links with the 
state ${ }^{37}$ which would provide a more nuanced discussion of the evolution of resources and capabilities. Our analysis is shaped by what data is available to us.

[Table 1 here]

We present a snapshot of our data in Table 1. The firm numbers are distributed into industry classifications (rows 1 to 8). The average age of firms trading in 1901 and 1930 is shown in columns 5 and 6; the average size of firms trading at those dates in columns 7 and 8; and the average profitability of all firms trading between 1901 and 1930 in column 9 . We have collected data on other firms' characteristics that might have a bearing on longevity: the number of foreign owned firms that might be thought $a$ priori to have superior resources and capabilities to domestic firms; those firms that were price takers in international markets; firms exiting as a consequence of being wound up or delisted, signifying that their resources and capabilities had least value to other firms; and those firms in the top and bottom quartile of profitability.

Our data for the firms' variables of size and profitability is taken from companies' financial statements as reported in the Australasian Insurance and Banking Review. Data on each firm's age at 1901, its whole of life-longevity, date of entry and exit, as well as the nature of its exit has been extracted from a variety of sources. ${ }^{38} \mathrm{We}$ have excluded from the sample those firms for which we could not provide a start and/or end date and those whose accounts made it difficult to extract a meaningful net profit figure, notably mutual associations, many of the insurance companies and some of the mining companies. This is less than 10 per cent of our firms.

Longevity, our dependent variable, is measured as the span of years between birth that for most firms is before 1901 and exit up to 1930. Our measure of the year of birth is registration as a corporation, either a private or public company. Clearly, most of our sample firms would have been trading before that point but it would be impossible to trace the origins of such a large number of firms. The act of incorporation and acceptance of the regulatory obligations mark a turning point, when the firm achieves a stage of permanency and capacity that sets it apart from the mass of sole proprietors and partnerships.

Dating exit also poses some challenges. ${ }^{39}$ Our definition of 'exit' follows the listing requirements of the Australian Stock Exchange (ASX), that is, the independent status of a 
firm lapses when its securities are no longer traded. Firms can be liquidated or wound up, or are delisted at the request of the shareholders. ASX records also show that delisting can be triggered by a change of name. For a small number of cases of firms exiting in the 1970s and 1980s renaming was probably the result of corporate restructuring, for example, the creation of a holding company, rather than an ending of the business. However, we treat delisting as an exit. ${ }^{40}$ Most of those on our list of exits appear as a result of take-over, with their physical assets, key personnel, patents and brands acquired by another set of owners, but as the listed securities issued by absorbed firms are retired.

Business historians have employed various measures of firm size - paid up and market value of capital, workforce, sales and total assets. We have chosen to use total assets since it is the best measure available to us as it appears on annual balance sheet reports. There is no data for the market capital, sales or workforces for most of our firms during these years. ${ }^{41}$

Our measure of annual rate of return on equity (ROE), is net profits divided by total shareholders' funds (TSF), the latter being a mix of paid ordinary share capital and accumulated reserves from earlier profits. ${ }^{42}$ It should be noted that the accounting standards of the day permitted firms wide latitude in the calculations of both net profits and in the value of reserves. ${ }^{43} \mathrm{We}$ are forced to accept the data at face value while acknowledging that accounting practices will provide an upward bias to ROE figures by overestimating net profit and, because of 'hidden reserves', underestimating total shareholder funds. ${ }^{44}$ However, we believe that this bias will be very small.

It might be argued that ROE is not independent of either firm size or age, giving rise to multicollinearity. Larger and older firms may have accumulated greater resources and experience that might generate higher rates of return than smaller and younger firms. However, we have no reason to predict, a priori, that such a distinction would hold. One counter argument is that younger and smaller firms have advantages in not having been trapped in path dependencies. They may be better prepared for adopting new practices. A simple correlation matrix (see Table 2) shows that the correlation level between age, size and profitability among firms in our sample is low. Furthermore, we address the existence of multicollinearity in our quantitative testing by performing a Variance Inflation Factor (VIF) test.

[Table 2 here] 


\section{Methodology and results}

We analyse firms' likelihood of survival using duration analysis. We start by computing the survival function $(\hat{S})$ of the 349 firms in our sample, illustrated in Figure 1, some of which survive to the present day. This represents the probability of firms' survival past time $t$, calculated using the Kaplan-Meier estimator: ${ }^{45}$

$\hat{S}(t)=\prod_{j \mid t j<t} \frac{n j-d j}{n j}$

Where $n_{j}$ is the number of firms under risk of failure at time $t_{j}$ (i.e. all the firms that have not failed by time $t j$ ) and $d_{j}$ represents the number of firms exiting at time $t_{j}$. We have grouped firms' key exit causes in four categories: name change, wound up/liquidation, deregistration, and takeover/merger.

[Figure 1 here]

By 1910, 3.15 per cent of the firms operating in 1901 had exited the market; by 1920 company failures had risen to 15.19 per cent and by 1930 to 28.65 per cent; three firms from the sample are still operating in $2016 .^{46}$

To estimate the factors impacting firm survival we use the Cox proportional hazards regression model, according to which the $j$ th firm's hazard rate $h$ is: ${ }^{47}$

$h\left(t \mid X_{j}\right)=h_{0}(t) \exp \left(X_{j} \beta_{x}\right)$

where $X_{j}$ is a vector of firm specific variables and $h_{0}(t)$ represents the baseline function. ${ }^{48}$ Specifically, our baseline regressions take the following form:

$h(t \mid X)=h_{0}(t) \exp \left(\beta_{1} R O E+\beta_{2}\right.$ age $+\beta 3$ size $)$

Where:

ROE $=$ Net Profits/ total shareholders' funds (TSF), averaged between 1901 and 1930.

Age $=$ the firm's age when it exits the market, calculated as follows:

$A=A_{E}-A_{1}$ if $A_{E}<1930$ or $A=1930-A_{1}$ if $A_{E} \geq 1930$ 
Where:

$\mathrm{A}=$ firm's age in 1930

$A_{E}=$ firm's year of exit

$A_{1}=$ firm's year of birth

Size $=$ the firm's size, measured as total assets, averaged between 1901 and 1930.

We also estimate all regressions using ASIC fixed effects, to account for unobservable variation at the ASIC level. We proceed in two ways: we include indicator variables for each ASIC category, assuming that these have a direct multiplicative effect on the hazard function. Alternatively, we estimate stratified models to allow baseline hazards to vary across the eight ASIC categories. Thus the hazard function becomes:

$h\left(t \mid x_{j}\right)=h_{0 i, k \in K}(t) \exp \left(x_{j} \beta_{x}\right), \mathrm{K}=\{1, \ldots .8\}$

where $\mathrm{K}$ includes all ASIC groups.

The analysis is performed using 1930 as the benchmark year for exit. We chose two different entry points. First we follow only the firms that entered the market up to 1901 . Then, we include 110 new entrants by adding firms established between 1902 and 1921, 28 of which exited the market by $1930 .^{49}$

The results in Table 3 represent the hazard ratios, indicating the impact of a unit change in an explanatory variable to the conditional probability of 'surviving', that is, of notexiting the market. Hazard ratios lower (greater) than 1 have a negative (positive) impact on the hazard rate (that is, on the likelihood of failing). All specifications use robust standard errors clustered at the company level. Columns 1 to 3 refer to the 1901 firms' sample, while columns 4 to 6 refer to the database including new entrants.

The findings indicate that profitability is consistently significant for both samples, across specifications. A one percent increase in firms' average ROE increases firms' likelihood to survive, on average, by 4.3 per cent (1901 sample) and 1.1 per cent (extended sample), depending on the specification. A firm's age also contributes positively to its longevity, with older firms exhibiting a higher probability of surviving in all models: on average a one year increase in age translates into a lower probability of failing by 10.3 per cent (1901 sample) and 4.4 per cent (extended sample). On the other hand, perhaps surprisingly, firms' size had no impact on longevity. In the 1901 sample the coefficient is significant but has a value of one, implying a zero impact on the likelihood of survival. ${ }^{50}$ In 
the extended sample the coefficient is no longer significant. We performed a VIF multicollinearity test for both samples: their values are very low, 1.20 (1901 sample) and 1.13 (extended sample), pointing to the absence of multicollinearity.

[Table 3 here]

\subsection{Robustness tests}

In order to test the strength of our results, we perform a set of additional robustness tests, following our discussion of the firms' categories as presented in Table 1. The results are reported in Table 4 (1901 sample), Table 5 (extended sample) and Table 6. First we divide firms into domestic-oriented and exporters, thus distinguishing between companies catering for local demand and export-oriented ones (Tables 4 and 5, columns 1 and 2): arguably, firms supplying different types of markets may have been exposed to different macroeconomic and institutional settings, local versus global. Then we exclude from the sample firms that exited the market for reasons other than being merged with or taken over by another company (Tables 4 and 5, column 3). In columns 4 and 5 (Tables 4 and 5) we eliminate the firms with top and bottom 25\% ROE between 1901 and 1930, respectively, in order to check if the largest or smallest firms in the sample were the main determinants of our results. Finally we test whether being a financial firm (Tables 4 and 5, column 6) or being foreign owned (Tables 4 and 5, column 7) were important drivers of firm survival. For this purpose, we created two dummy variables: financial equal to one if a company was a financial firm and zero otherwise; and foreign equal to one if a company was foreign owned and zero otherwise. We find that our results remain unaltered in both samples, with age and ROE remaining the key drivers of longevity.

Another concern about specific industry characteristics that may have impacted longevity differently arises from a firm's location. As Australia in the early twentieth century was a thinly populated country, with Sydney and Melbourne as major urban centres, it is sensible to enquire whether firms' longevity was influenced by geography. In order to account for the role of location, which in turn may also have implications in terms of population density, we examine whether there were any regional differences across our sample of firms in two ways. First we add state fixed effects, using New South Wales (NSW) as base category (Table 6, columns 1,2); then we run two separate regressions: one with New 
South Wales and Victoria's firms (columns 3, 4) and one with the remaining states (columns $5,6)$. We show that none of the states behaved differently from NSW, as the state-dummy coefficients were not significant. Furthermore, the regressions' results in columns 2 and 3 are similar, confirming our baseline findings on the role of profitability and age. As a final robustness check, we investigate whether a key policy mechanism of the period - tariff protection, which applied to much of manufacturing industry, mattered for firms' survival. We have tested for this effect by assigning a dummy of 1 to firms likely to receive tariff protection, that is, manufacturers, and zero otherwise. The results in Table 6 (columns 7, 8) are interesting and enrich the paper as they show that for these firms, about 25 per cent of our sample, profitability did not matter for longevity, but size did. The likely explanation of this is that manufacturing production generally provided greater scope for economies of scale as a competitive tool than most services and rural industries. ${ }^{51}$

[Table 4 here]

[Table 5 here]

[Table 6 here]

\section{Discussion}

The most surprising result is that size has no impact on a firm's longevity, other than in manufacturing. Size may bring operational efficiency and power advantages such as scale economies and greater market concentration. However, it remains an open question in the, largely contemporary, economics literature whether these benefits endure over time. ${ }^{52}$ As we saw in section 2, management scholars have sought to examine more specifically the type of life-extending competitive capabilities that a well-resourced firm may develop; although whether scale is critical to this resource-based view of success remains empirically unproven.

Much of the business history literature has placed large-scale enterprise at the centre of the narrative. Scholars have followed the highly influential work of Alfred Chandler in emphasising the superior efficiency properties of large firms that invested heavily in management, marketing and mass production to overcome the potential diseconomies of 
growth. ${ }^{53}$ In Chandler's wake, business historians replicated his work by supplying a large volume of empirical data, particularly constructing statistical series of the 'largest' firms in many countries over long periods of time. Les Hannah compiled an extensive global list of firms from which he calculated that larger firms, so-called giant redwoods, survived the longest and concluded that this was due to access to a superior set of resources. ${ }^{54}$ However, there are weaknesses with this literature. In particular, in describing the qualities of larger firms it assumed that big business was a superior form of enterprise without specifically testing this assumption against smaller enterprises, and it focussed primarily on the manufacturing sector where the benefits of size may have mattered more than elsewhere in the economy.

In recent years, though, business historians have begun to shift focus to look elsewhere for corporate success. They have started to explore more closely the boundaries between Chandler's ideal type of a large modern firm, characterised by a separation of ownership from control, with the persistence of family firms and business groups of varying sizes. ${ }^{55}$ Another group of scholars have devoted their attention to the act of creating the enterprise, the role of the individual entrepreneur. ${ }^{56}$ Others have explored issues of longevity through 'whole of life' biographies of individual companies, or major industries over a very long time period. ${ }^{57}$ The small and medium enterprises sector, and the cooperative spaces between such firms, has also received growing attention. ${ }^{58}$ However, in neither the original focus on big business nor the more recent change of direction has there been a serious attempt to estimate, using quantitative data, whether size is a critical determinant of long term differences in survivorship.

A firm's age was found to be significant for its subsequent survival. Like size, the relationship between age and longevity lacks theoretical clarity as different disciplines using varied methodologies have reach no agreed conclusions. The shortcomings of newness, adolescence and obsolescence, respectively, have all been interrogated. ${ }^{59}$ Like individuals, firms learn from their experiences in a manner that can better prepare them for subsequent shocks. Internal capabilities may develop over time that enable firms to perform more productively and adapt organically to changes in their business orientation or the environment. Indeed, firms can improve their external environment, so-called industry attractiveness, by adopting Porter's generic strategies of low cost or differentiation, to reduce the corrosive effects of competition. ${ }^{60}$ The positive association of age with survivorship 
suggests, therefore, that the benefits of maturity outweigh what Hannah calls the 'liability of senescence', and in turn that new firms are most vulnerable to failure. ${ }^{61}$

Profits also influenced survivorship amongst our firms. The theorised relationship between the two, however, is multi-dimensional. A high rate of return provides a firm with funds that may insulate it against failure in hard times. It also provides the opportunity for further growth through internal funding or access to debt and new equity. Profits may, further, be invested in doing existing tasks better or adapting to changes in the market, such as diversification strategies rather than pursuing growth per se. Against these positive associations, measures to increase short term profitability may also impact on the long term investment and survival of a firm, although the persistence of profits hypothesis suggests that firms that have high rates of return relative to competitors at the beginning of the period have a high probability of maintaining this into the future. ${ }^{62}$

Finally, it is important to note that our results focus on a particular national context the Australian economy in the first third of the twentieth century - whose key characteristics were summarized in section three. The economy consisted of firms from most sectors, which included manufacturing but also many from natural resources, the latter being largely absent from many business history studies of large industrial economies. In addition, even the largest firms were minnows compared with their overseas counterparts. ${ }^{63}$ We saw above that it was only among manufacturing firms that size rather than profitability was a driver of longevity as firms sought to expand to gain the benefits of plant economies of scale. The lack of importance of size with the respect to the whole sample reflects the structural characteristics of the Australian economy during this period, a large resource and service sector where economies of scale mattered less.

Besides structural questions of size and sectoral orientation, the quality of entrepreneurship plays a role in the longevity of individual firms in any economy. The quality of decision making, whether located in small family firms, as part of groups, or of large public companies, matters. Across the spectrum of business forms in twentieth-century Australia, there is ample evidence of smart entrepreneurship. Some of the largest firms endured by responding to changing environments and by investing in internal management systems. Major firms such as iron and steel producer, BHP, sugar refiner, CSR, and glass maker, Australian Glass Manufacturer, for example, survived by diversifying their operations into new products and processes in response to market conditions. ${ }^{64}$ Equally, in small and medium-sized firms entrepreneurs responded to their environment particularly by building 
cooperative relationships with other firms in their industry or supply chain, which mimicked the benefits of scale afforded larger firms. In the highly successful Australian wool marketing industry, for example, the stock and station agents demonstrated 'institutional entrepreneurship' by developing a new and highly efficient business model in the form of the local wool auction system. These firms, through iterative learning processes, balanced cooperative auction selling with competitive behaviour in other areas of their operations such as pastoral finance. Some of these firms were the largest corporations of the early twentieth century, but other active players were relatively junior. ${ }^{65}$

There may indeed be elements of the Australian corporate environment that suggest the best entrepreneurs were less likely to be concentrated in the largest firms than in an economy like the USA. The growth of a professional managerial class in America by the early decades of the twentieth century provided a flow of highly trained executives into specialist positions in the largest corporations. ${ }^{66}$ In Australia the separation of ownership from control and concomitant growth of a professional executive class came much later in the twentieth century. Leadership positions in many of the largest firms remained closely held in the hands of family dynasties irrespective of the varying talents of each generation. Smaller scale and cooperative entrepreneurship was helped by personal connections in closely networked business communities that had been enriched by deep seams of social capital. ${ }^{67}$

Overall, our judgment is that competitive advantage and barriers to entry derived heavily from types of activity by, and among, firms and their entrepreneurs that could be created independently of scale. These included, in particular, the protection of proprietary intellectual capital through patents and trademarks, brand building, market expansion, favoured access to capital, and the ownership of valuable strategic assets, especially in mining. ${ }^{68}$ All of these weakened the link between size and survival.

If our results are largely contingent upon factors in the Australian business environment, they were not unique because other economies in parts of Europe, Latin America and South Africa shared some similar characteristics - late managerial development, natural resource industries, small economy, multinational penetration - all suggesting the implications of our results have broader applicability beyond Australia. ${ }^{69}$ Indeed, it may well have been the case that the business history literature for long chased, in America, an exception to a more common picture. 


\section{Conclusion}

Survivorship is an important marker of a firm's performance since it shows a sustained ability to compete successfully and respond to environmental shocks and opportunities. An extensive literature across several disciplines - business history, economics, management, organisational studies - points to several possible high order explanations of longevity, notably size and age, and profitability. None of these disciplines convincingly provides an explanation of longevity in our opinion. Business history assumes size is better by narrating many histories of big business, empirical testing in economics focusses on periods too short to reveal the full story, while management research is preoccupied with hypothesis-building.

We deploy long term evidence of a wide sample of Australian firms that traces their origins back to the nineteenth century, details their profitability early in the twentieth century, and carries the survivorship evidence forward across several decades. The most surprising outcome is that size did not matter, except for manufacturing. This result sits uneasily with several strands of research - the view in business history that large firms drove corporate and economic development in many nations, in economics that size provided operational efficiency and the reach of market power, and in management that it facilitated capability building. In our results profitability and age mattered. It may be the case, therefore, that experience and reserves are more relevant than absolute size. Australia's context may have been different from those economies researched more extensively. Either way, we hope that these results will prove thought-provoking to researchers and motivate further work on the long term performance of business. 


\section{Bibliography}

Australian Stock Exchange. ASX Delisted Companies as at 30 June 1997: 1929-1997.

Sydney: Australian Stock Exchange Limited, 1997.

Bain, J. Barriers to New Competition: Their Character and Consequences in Manufacturing Industries. Cambridge, MA: Harvard University Press, 1956.

Bhidé, A. V. The Origin and Evolution of New Businesses. Oxford: Oxford University Press, 2000.

Blackford, M. G. A History of Small Business in America. New York: Twayne Publishers, 1991.

Boyce, G. "A professional association as a network and communicating node: The Pharmaceutical Society of Victoria." Australian Economic History Review 39, no. 3 (1999): 258-283.

Butlin, Matthew, Robert Dixon, and Peter J. Lloyd. "Statistical appendix: Selected data series, 1800 - 2010.” In The Cambridge Economic History of Australia, edited by Simon Ville and Glenn Withers, 555 - 594. Melbourne: Cambridge University Press, 2015.

Caldwell, J. C. "Population." In Australians Historical Statistics, edited by Wray Vamplew. Sydney: Farfaix, Syme and Weldon Associates, 1987.

Cassis, Y. Big Business: The European Experience in the Twentieth Century. Oxford: Oxford University Press, 1997.

Chandler, A. D. Jr. Strategy and Structure: Chapters in the History of the American Industrial Enterprise. Cambridge, MA: The MIT Press, 1962.

Chandler, A. D. Jr. The Visible Hand: The Mangerail Revolution in American Business. Cambridge, MA: Belknap Press of Harvard University Press, 1977.

Chandler, A. D. Jr., F. Amatori, and T. Hikino. Big Business and the Wealth of Nations. Cambridge: Cambridge University Press, 1999.

Collins, J. C. and Porras, J. I., Built to Last: Successful Habits of Visionary Companies, New York: Harper Collins, 1994. 
Colli, A., and M. B. Rose. "Family firms in a comparative perspective." In Business History around the World, edited by Franco Amatori and Geoffrey Jones, 341-346. Cambridge: Cambridge University Press, 2003.

Colli, A., Howorth, C. and Rose, M. "Long-term perspectives on family business." In Business History, 55, no. 6 (2013): 841-854.

Colpan, A. M., T. Hikino, and J. R. Lincoln, eds. The Oxford Handbook of Business Groups. Oxford: Oxford University Press, 2010.

DeYoung, Robert. "The failure of new entrants in commercial banking markets: a splitpopulation duration analysis." Review of Financial Economics 12, no. 1 (2003): 7-33.

Eloranta, J., J. Ojala, and H. Valtonen. "Quantitative Methods in Business History: An Impossible Equation?” Management \& Organizational History 5, no. 1 (2010): 79_ 107.

Fleming, Grant, David Merrett, and Simon Ville. The Big End of Town: Big Business and Corporate Leadership in Twentieth-Century Australia. Cambridge, MA: Cambridge University Press, 2004.

Geroski, P. A., J. Mata, and P. Portugal. "Founding Conditions and the Survival of New Firms." Strategic Management Journal 31, no. 5 (2010): 510-29.

Gibson, R. W. Disclosure by Australian Companies. Melbourne: Melbourne University Press, 1971.

Giovannetti, G., G. Ricchiuti, and M. Velucchi. "Size, Innovation and Internationalization: A Survival Analysis of Italian Firms.” Applied Economics 43, no. 12 (2011): 1511-20.

Grant, R. M. Contemporary Strategy Analysis and Cases: Text and Cases. 5th ed. Hoboken: John Wiley \& Sons, 2005.

Hall, A. Australian Company Finance: Sources and Uses of Funds of Public Companies, 1946-1955. Social Science Monographs. Canberra: Australian National University, 1956.

Hamel, G., and A. Heene. Competence-Based Competition. Hoboken: John Wiley \& Sons, 1994.

Hannah, L. "The 'Divorce' of Ownership and Control from 1900 Onwards: Re-calibrating Imagined Global Trends." Business History 49, no. 4 (2007): 404-38. 
Hannah, L. "Marshall's 'trees' and the global 'forest': were the giant redwoods different?" In Learning by Doing in Markets, Firms and Countries, edited by N. R. Lamoreaux, G. Raff and P. Temin. Chicago: University of Chicago Press, 1999.

Hannah, M. "Rethinking Age Dependence in Organizational Mortality: Logical Formalizations." American Journal of Sociology 104, no. 1 (1998): 126-164.

Harrop, M. Good Things Come From Glass: The History of Glass Making in Australia 18121987. Melbourne: Melbourne University Press, 2008.

Hatton, T. J., and B. J. Chapman. "Apprenticeship and technical training." in Australia's Greatest Asset: Human Resources in the Nineteenth and Twentieth Centuries, edited by D. Pope, and L. Alston, 130-56. Sydney: Federation Press, 1989.

Hatton, T., and G. Withers. "The labour market" in The Cambridge Economic History of Australia, edited by Simon Ville and Glenn Withers, 351 - 72. Melbourne: Cambridge University Press, 2015.

Hogarth, Robin, Claude Michaud, Yves Doz, and Ludo van der Heyden. Longevity of Business Firms: A Four-stage Framework for Analysis. Fontainebleau: INSEAD, 1991.

Holmes, P., A. Hunt, and I. Stone. "An Analysis of New Firm Survival Using a Hazard Function.” Applied Economics 42, no. 2 (2010): 185-95.

Huntleys. Huntleys' Delisted Companies Report 2001, 1929 to June 2001. Mosman, NSW, 2001.

Huynh, K. P., R. J. Petrunia, and M. Voia. "The Impact of Initial Financial State on Firm Duration across Entry Cohorts.” The Journal of Industrial Economics 58, no. 3 (2010): 661-89.

Jobson's Australian Investment Digest, Sydney: Jobson's Publications, 1927 - 1970.

Jones, G. Beauty Imagined: A History of the Global Beauty Industry. Oxford: Oxford University Press, 2010.

Jones, G. British Multinational Banking, 1830-1990. Oxford: Clarendon Press, 1985.

Jones, G. "Multinational chocolate: Cadbury overseas, 1918-39." Business History 26, no. 1 (1984): $59-76$. 
Jovanovic, B. "Selection and the Evolution of Industry." Econometrica 50, no. 3 (1982): 649670.

Kalbfleisch, J. D., and R. L. Prentice. The Statistical Analysis of Failure Time Data. New York: Wiley, 2002.

Karmel, P. H., and M. Brunt. The Structure of the Australian Economy. Melbourne: F. W. Cheshire, 1962.

Laird, P. Pull: Networking and Success since Benjamin Franklin. Cambridge MA: Harvard University Press, 2006.

Mackinnon, M. “Schooling: Examining some myths”, In Australia’s Greatest Asset: Human Resources in the Nineteenth and Twentieth Centuries, edited by D. Pope, and L. Alston, 102 - 29. Sydney: Federation Press, 1989.

Marshall A. The Principles of Economics. $8^{\text {th }}$ ed. London: Macmillan, 1920.

Magee, G. B. “Technological change.” In The Cambridge Economic History of Australia, edited by Simon Ville and Glenn Withers, 125 - 49. Melbourne: Cambridge University Press, 2015.

Magee, G. B., and A. S. Thompson. Empire and Globalisation: Networks of People, Goods and capital in the British World, c.1850-1914. Cambridge: Cambridge University Press, 2010.

McGahan, A. M. How Industries Evolve: Principles for Achieving and Sustaining Superior Performance. Cambridge, MA: Harvard Business Press, 2004.

McLean, I. W. "Savings", In Saving and Policy: Proceeding of a Conference, edited by Peter J. Stemp. Canberra: ANU Centre of Economic Policy Research, 1991.

McLean, I. W. Why Australia Prospered: The Shifting Sources of Economic Growth. Princeton: Princeton University Press, 2013.

Merrett, D. T. “The Australian bank crashes of the 1890s revisited." Business History Review 87, no. 3 (2013): 407-430.

Merrett, D. T. “Australia's emergent multinationals: The legacy of having a natural resource intensive, small and closed economy as home." International Studies in Management and Organization 32, no. 1 (2002): 109-35. 
Merrett, D. "Australian Firms Abroad Before 1970: Why So Few, Why Those, and Why There?" Business History 44, no. 2 (2002): 65-87.

Merrett, D. T. "Capital markets and capital formation in Australia, 1890-1945.” Australian Economic History Review 37, no. 3 (1997): 181-201.

Merrett, D., S. Morgan, and S. Ville. "Industry Associations as Facilitators of Social Capital: the Early Operations of the Melbourne Woolbrokers Association." Business History 50, no. 6 (2008): 781-794.

Merrett, D. T., and S. Ville. "Financing growth: New issues by Australian firms, 1920-1939." Business History Review 83, no. 3 (2009): 563-589.

Merrett, D., and S. Ville. "Institution Building and Variation in the Formation of the Australian Wool Market." Australian Economic History Review 53, no. 2 (2013): 14666.

Merrett, D., and S. Ville. "Tariffs, Subsidies, And Profits: A Re-Assessment Of Structural Change In Australia 1901-39.” Australian Economic History Review 51, no. 1 (2011): $46-70$.

Mueller, D. C. The Dynamics of Company Profits: Profits and the Process of Competition. The Dynamics of Company Profits. Cambridge: Cambridge University Press, 1990.

Murmann, J. P., Knowledge and Competitive Advantage: The Coevolution of Firms, Technology, and National Institutions, Cambridge: Cambridge University Press, 2003.

Napolitano, M. R., V. Marino, and J. Ojala. "In search of an integrated framework of business longevity." Business History 57, no. 7 (2015): 955-969.

Nash, R. L. The Australasian Joint Stock Companies' Year Book. Sydney, 1896 - 1914.

Pérez, S. E., A. S. Llopis, and J. A. S. Llopis. "The Determinants of Survival of Spanish Manufacturing Firms.” Review of Industrial Organization 25, no. 3 (2004): 251-73.

Pérez, P. F. and Colli, A., editors, The Endurance of Family Businesses: A Global Overview, Cambridge: Cambridge University Press, 2013.

Porter, M. E. Competitive Advantage: Creating and Sustaining Superior Performance. Competitive Advantage: Creating and Sustaining Superior Performance. New York: Free Press, 1985. 
Porter, M. E. Competitive Strategy: Techniques for Analyzing Industries and Competition. New York. New York: Free Press, 1980.

Report of the Royal Commission Appointed to Inquire into the Monetary and Banking Systems at Present in Operation in Australia. Canberra: Government Printer, 1937.

Riviezzo, A., M. Skippari, and A. Garofano. "Who Wants to Live Forever: Exploring 30 Years of Research on Business Longevity.” Business History 57, no. 1 (2015): 1-18.

Schedvin, C. B. Australia and the Great Depression: A Study of Economic Development and Policy in the 1920s and 1930s. Sydney: Sydney University Press, 1970.

Schedvin, C. B. Shaping Science and Industry: A History of Australia's Council for Scientific and Industrial Research, 1926-49. Sydney: Allen and Unwin, 1987.

Scott, E. Australia during the War: The Official History of Australia during the War of 191418. Volume XI. Sydney: Angus and Robertson, 1938.

Sheridan, K. The Firm in Australia: A Theoretical and Empirical Study of Size, Growth and Profitability. Melbourne: Thomas Nelson, 1974.

Stadler, C., Enduring Success: What Can We Learn from the History of Outstanding Corportaions, Standford: Standford Business Books, 2011.

Stanton, J. "Protection, market structure, and firm behaviour: inefficiency in the early Australian tyre industry." Australian Economic History Review 24, no. 2 (1984): 91 114.

Teece, David J. Dynamic Capabilities and Strategic Management. Oxford: Oxford University Press, 2009.

The Stock Exchange of Melbourne Official Record. Melbourne, 1930.

The "Wild Cat" Monthly. Sydney, various.

Verbeke, A. International Business Strategy. $2^{\text {nd }}$ ed. Cambridge: Cambridge University Press, 2013.

Ville, S. “Colonial enterprise.” In The Cambridge Economic History of Australia, edited by Simon Ville and Glenn Withers, 202 - 221. Melbourne: Cambridge University Press, 2015. 
Ville, S., and D. Merrett. "A Time Series for Business Profitability in Twentieth-Century Australia." Australian Economic Review 39, no. 3 (2006): 330-9.

Wadham, S. M., and G. L. Wood. Land Utilization in Australia. $2^{\text {nd }}$ ed. Melbourne: Melbourne University Press, 1952.

Wheelwright, E. L. Ownership and control of Australian Companies: A Study of 102 of the Largest Public Companies Incorporated in Australia. Sydney: Law Book Co, 1957.

Wilson, M., and G. Shailer. "Political costs, income measurement and disclosure: a case study from the brewing industry." School of Business and Information Management, Australian National University, 2004. 


\section{Notes}

1. Napolitano, Marino and Ojala, "Business longevity".

2. Riviezzo, Skippari and Garofano, 'Who wants to live forever'.

3. Marshall, The Principles of Economics.

4. Including economics, sociology, management studies, organisational studies, and business history.

5. Napolitano, Marino and Ojala, "Business longevity"; Riviezzo, Skippari and Garofano, "Who wants to live forever"; Cassis, Big Business.

${ }^{6}$ Collins and Porras, Built to Last; Stadler, Enduring Success.

7. Riviezzo, Skippari and Garofano, 'Who wants to live forever', 979.

8. In particular, see Porter, Competitive Strategy; Porter, Competitive Advantage; McGahan, How Industries

Evolve.

9. Teece, Dynamic Capabilities.

10. See Hamel and Heene, Competence-Based Competition; Grant, Contemporary Strategy Analysis; Verbeke, International Business Strategy, chapter 2.

11. Napolitano, Marino and Ojala, "Business longevity", 956.

12. Chandler, Strategy and Structure; Chandler, The Visible Hand; Chandler and Hikino, Scale and Scope.

13. Riviezzo, Skippari and Garofano, "Who wants to live forever".

14. Support for greater integration of methodologies between business history, economic history, and management scholars comes from Eloranta, Ojala and Valtonen, "Quantitative Methods in Business History". 15. Napolitano, Marino and Ojala, "Business longevity", p. 958

${ }^{16}$ Hannan and Freeman, Organizational Ecology. Johann Murmann (Knowledge and Competitive Advantage, 197), notes the weakness of the organizational ecology approach arguing that “...it cannot deal with nor account for the fact that many firms successfully shaped their selection environment and that many of them changed their internal structures".

17. Magee and Thompson, Empire and Globalisation; McLean, Why Australia Prospered.

18. Merrett, "Australian Bank Crashes"; Scott, Australia During the War; Schedvin, Australia and the Great Depression.

19. Butlin, Dixon and Lloyd, "Statistical Appendix", table 2, 564-5.

20. Mackinnon, "Schooling"; Hatton and Chapman, "Apprenticeship and technical training"; Hatton and Withers, "The labour market".

21. McLean, "Savings", table 2, 9; Merrett, "Capital markets and capital formation"; Merrett and Ville, "Financing growth".

22. Magee, "Technological change"; Schedvin, Shaping Science and Industry.

23. Merrett and Ville, "Tariffs, subsidies and profits".

24. Wadham and Wood, Land Utilization in Australia.

25. Ville, "Colonial enterprise", 221.

26. The first decade of the twentieth century saw the number of incorporated non-mining firms rise from 504 to 2320, while the number of firms listed on the Melbourne and Sydney Stock Exchanges grew by nearly 70 per cent in the 1920s. See Merrett and Ville, "Financing growth", 567, 569.

27. Fleming, Merrett and Ville, The Big End of Town. An examination of shareholdings of 39 firms in our sample in the early 1950s shows a marked shift away from ownership and control by founding families and friends, a third of the companies, towards a clear majority of more dispersed shareholdings, cross company holdings and ownership by foreign firms, which transferred greater control to managers. See Wheelwright, Ownership and Control.

28. Boyce, "The Pharmaceutical Society of Victoria".

29. Chandler and Hikino, Scale and Scope.

30. Caldwell, "Population", POP 17-25, 26.

31. Fleming, Merrett and Ville, The Big End of Town, 31-36. 
32. For an account of leading firms in Australia during the twentieth century see Fleming, Merrett and Ville, The Big End of Town.

33. Fleming, Merrett and Ville, The Big End of Town; Ville and Merrett, "A Time Series for Business Profitability", 332 for more information on this source.

34. A similar methodology has been adopted by Geroski, Mata and Portugal, "Founding conditions"; DeYoung, "The failure of new entrants".

35. Merrett, "Australia's emergent multinationals".

${ }^{36}$ Butlin, Barnard and Pincus, Government and Capitalism.

${ }^{37}$ Cassis, Big Business, Parts III and IV.

38. Most of this data has been drawn from Nash, Joint Stock Companies' Year Book. Additional information was found in company histories and searches on Trove.

39. We have used a variety of sources including company histories, Jobson's Australian Investment Digest, internet searches including Trove, and stock exchange records.

40. Australian Stock Exchange, ASX Delisted Companies; Huntleys, Huntleys' Delisted Companies.

41. For a discussion of the different measures used by business historians see Fleming, Merrett and Ville, The

Big End of Town, 4-5, footnotes 12-16.

42. Preference shares and debentures are excluded. For a discussion of the various alternatives see Ville and Merrett, “A Time Series for Business Profitability”, 330-1, footnote 4.

43. Gibson, Disclosure by Australian Companies.

44. See Hall, Australian Company Finance, 8-12. Hidden reserves were commonly used by trading banks, see Report of Royal Commission, 241-46. For breweries, see Wilson and Shailer, "Political costs".

45. Kalbfleisch and Prentice, Failure Time Data, 14-16.

46. These are: Australian Gas-Light Co, Sydney; Standard Life Association Ltd; and Washington H. Soul, Pattinson and Co Ltd, Sydney.

47. The Cox model is semi-parametric: it does not specify any parametric form of the survivor's function, while the effects of the covariates are parametrised to alter the baseline survivor's function. It is widely used in survival analysis. For technical details see Kalbfleisch and Prentice, Failure Time Data.

48. By not specifying the baseline function the Cox proportional hazard model overcomes the potential issue of unobserved heterogeneity.

49. The choice of these years is driven by data availability on ROE and total assets starting in 1901 and on firms' entry up to 1921 .

50. The formula to calculate the impact of a coefficient $\beta$ is $\exp (\beta)-1$. As we are reporting exponentiated coefficients, we just need to subtract one.

${ }^{51}$ These results engage with a debate about the drivers of sectoral change in Australia. Merrett and Ville, "Tariffs, subsidies and profits".

52. See Jovanovic, "Evolution of Industry"; Huynh, Petrunia and Voia, "The impact of initial financial state"; Giovannetti, Ricchiuti and Velucchi, "Size, innovation and internationalisation"; Holmes, Hunt and Stone,

"New firm survival"; Geroski, Mata and Portugal, "Founding conditions".

53. Chandler, Strategy and Structure; Chandler, The Visible Hand.

54. Hannah, "Marshall's 'trees".

55. Hannah, "The 'Divorce' of Ownership and Control"; Colli and Rose, "Family firms in a comparative perspective"; Colpan, Hikino and Lincoln, Oxford Handbook of Business Groups; Colli, Howorth and Rose, "Long-term perspectives; Pérez and Colli, Endurance of Family Businesses.

56. Bhidé, The Origin and Evolution.

57. Jones, British Multinational Banking; Jones, Beauty Imagined.

58. Blackford, Small Business in America was a pioneer. See also Laird, Pull.

59. Riviezzo, Skippari and Garofano, "Who Wants to Live Forever"; Pérez, Llopis and Llopis, "The

Determinants of Survival"; Hannah, "Rethinking Age Dependence".

60. Porter, Competitive Advantage.

61. Hannah, "Rethinking Age Dependence".

62. Hogarth et al., Longevity of Business Firms, 18; Mueller, The Dynamics of Company Profits. 
63. Fleming, Merrett and Ville, The Big End of Town, 29.

64. Fleming, Merrett and Ville, The Big End of Town, 104-6; Harrop, Good Things Come From Glass, 87.

65. Merrett and Ville, "Institution Building and Variation".

66. Chandler, The Visible Hand.

67. Merrett, Morgan and Ville, "Industry Associations".

68. Bain, Barriers to New Competition.

69. Norway for example shares feature of being resource-based economy, with a small population, and a high rate of inward FDI. 